\title{
Terapia ocupacional e pessoas trans: os impactos da cobrança social sobre o gênero
}

\author{
Occupational therapy and transgender persons: the impacts of social collection on gender \\ Terapia ocupacional y personas trans: los impactos de la facturación social en el género
}

Recebido: 24/11/2021 | Revisado: 02/12/2021 | Aceito: 06/12/2021 | Publicado: 16/12/2021

\author{
Raphaela Schiassi Hernandes \\ ORCID: https://orcid.org/0000-0002-9290-1003 \\ Universidade Federal de Sergipe, Brasil \\ E-mail: rapha_to@ hotmail.com. \\ Stéphanie Santana dos Santos Matos \\ ORCID: https://orcid.org/0000-0003-2060-3215 \\ Unidade de Acolhimento para crianças e adolescentes de Juazeiro do Norte, Brasil \\ E-mail: stetoufs@hotmail.com
}

\begin{abstract}
Resumo
O papel do homem e da mulher na sociedade é definido pelos seus órgãos sexuais, entretanto, pessoas que não se encaixam e identificam-se como sendo do gênero oposto questionam esse conceito, as pessoas trans. A cobrança de comportamentos e imagem corporal pode afetar a saúde mental e a vida social. A terapia ocupacional trabalha em diferentes contextos no cuidado às pessoas trans que por vezes enfrentam dificuldades nas suas relações e nos ambientes sociais. Objetivo geral: compreender e relatar os impactos sociais e mentais das noções de gênero sobre as pessoas trans, por meio de atividades expressivas utilizadas no encontro de terapia ocupacional. Objetivos específicos: compreender as maiores dificuldades e/ou preconceitos enfrentados pelas pessoas trans na sua infância e na sociedade atual; entender o quanto as opressões sociais afetam a saúde mental delas e o que almejam para essa melhora e descrever a compreensão sobre família, amor e sua expectativa para o futuro. A metodologia da pesquisa é qualitativa, com análise de discurso, que foram realizadas em um encontro, com um grupo de pessoas trans, com temáticas diversas. Foi possível perceber que o preconceito percorre toda a vida dessas pessoas, fazendo com que vivenciem situações de repressão e violência desde a infância, gerando o medo e a necessidade de lutar pela própria existência e pela liberdade de ser feliz sendo quem são, além disso, a sociedade tem papel fundamental na vida dessas pessoas, podendo ser fator de risco ou de proteção.
\end{abstract}

Palavras-chave: Pessoas transgênero; Socialização; Saúde mental.

\begin{abstract}
The role of men and women in society is defined by their sexual organs, however, people who do not fit in and identify themselves as being of the opposite gender question this concept, trans people. The collection of behavior and body image can affect mental health and social life. Occupational therapy works in different contexts in the care of transgender people who sometimes face difficulties in their relationships and in social environments. General objective: to understand and report the social and mental impacts of the notions of gender on trans people, through expressive activities used in the meeting of occupational therapy. Specific objectives: to understand the greatest difficulties and / or prejudices faced by trans people in their childhood and current society; understand how social oppression affects their mental health and what they crave for that improvement and describe their understanding of family, love and their expectations for the future. The methodology of the research is qualitative, with discourse analysis, which were carried out in a meeting, with a group of trans people, with diverse themes. It was possible to perceive that prejudice runs through the whole life of these people, causing them to experience situations of repression and violence from childhood, generating the fear and the need to fight for their very existence and for the freedom to be happy being who, society has a fundamental role in the lives of these people, and can be a risk or protection factor.
\end{abstract}

Keywords: Transgender persons; Socialization; Mental health.

\section{Resumen}

El rol de hombres y mujeres en la sociedad está definido por sus órganos sexuales, sin embargo, las personas que no encajan y se identifican como del género opuesto cuestionan este concepto, las personas trans. La demanda de comportamiento e imagen corporal puede afectar la salud mental y la vida social. La terapia ocupacional trabaja en diferentes contextos en el cuidado de personas trans que en ocasiones enfrentan dificultades en sus relaciones y entornos sociales. Objetivo general: comprender y reportar los impactos sociales y mentales de las nociones de género en las personas trans, a través de actividades expresivas utilizadas en la reunión de terapia ocupacional. Objetivos 
específicos: comprender las mayores dificultades y / o prejuicios que enfrentan las personas trans en su infancia y en la sociedad actual; comprender cómo la opresión social afecta su salud mental y lo que quieren mejorar y describir su comprensión de la familia, el amor y sus expectativas para el futuro. La metodología de investigación es cualitativa, con análisis de discursos, los cuales se llevaron a cabo en un encuentro, con un grupo de personas trans, con diferentes temáticas. Se pudo ver que el prejuicio recorre la vida de estas personas, provocando que vivan situaciones de represión y violencia desde la niñez, generando miedo y la necesidad de luchar por su propia existencia y por la libertad de ser felices siendo quienes son, además, la sociedad juega un papel fundamental en la vida de estas personas y puede ser un factor de riesgo o protector.

Palabras clave: Personas transgénero; Socialización; Salud mental.

\section{Introdução}

Para compreensão da dimensão do presente trabalho, terapia ocupacional e pessoas trans: os impactos da cobrança social sobre o gênero, é necessário fazer uma explanação sucinta sobre temáticas teóricas, para entendimento da prática realizada nesta pesquisa. Os temas abordados serão: o conceito de identidade de gênero; despatologização; discriminação e violências; direitos e políticas; e a Terapia Ocupacional.

Segundo autores contemporâneos, o gênero seria uma identidade estruturada socialmente, que surge para contestar a binaridade de gênero ligada ao órgão genital dos indivíduos como preconiza a biologia, podendo ser conceituada como:

1. É uma experiência interna e individual do gênero de cada pessoa, que pode ou não corresponder ao sexo atribuído no nascimento, incluindo o senso pessoal do corpo (que pode envolver, por livre escolha, modificação da aparência ou função corporal por meios médicos, cirúrgicos e outros) e outras expressões de gênero, inclusive vestimenta, modo de falar e maneirismos.

2. Identidade de gênero é a percepção que uma pessoa tem de si como sendo do gênero masculino, feminino ou de alguma combinação dos dois, independente de sexo biológico. Trata-se da convicção íntima de uma pessoa de ser do gênero masculino (homem) ou do gênero feminino (mulher) (ABGLT, 2018, p.16).

Segundo Judith Butler (2003), a ideia de gênero ligada ao sexo biológico é apenas produto da cultura de uma sociedade, sendo, portanto, homem ou mulher a definição de comportamentos sociais de pessoas cujos corpos podem fugir à heteronormatividade ${ }^{1}$. Com isso, uma pessoa com o órgão sexual dito "feminino" não precisaria identificar-se necessariamente como mulher, podendo ser também um homem trans, assim como uma pessoa com órgão sexual dito "masculino" não necessariamente se identificaria como homem, podendo ser uma mulher trans ou travesti. Assim, definir uma pessoa como homem ou mulher perante a sociedade não estaria mais restrito ao seu sexo, mas sim ao seu modo de se ver e identificar-se na sociedade, com o papel social e imagem corporal de homem ou mulher.

A vivência de uma pessoa trans é carregada de sofrimento desde seu início. Raimundo et al., (2021) afirma que vivências no ambiente escolar traz processos dolorosos, pois é carregado por desprezo e humilhação que percorre a repressão do uso de roupas que identificam seu gênero, o uso do banheiro que se reconhecem, o respeito do nome social, entre outras situações que evidenciam a transfobia e acarretam na evasão escolar.

Há o receio de frequentar também, os demais locais públicos, já que essa violência chega a tirar a vida de muitas pessoas trans, conforme dados da Associação Nacional de Travestis e Transexuais (ANTRA), que mostrou no Mapa dos Assassinatos de Travestis e Transexuais no Brasil de 2017, que ocorreram 179 assassinatos de pessoas Trans, sendo 169 Travestis e Mulheres Transexuais e 10 Homens Trans. Na maioria dos casos os suspeitos não são presos e os processos são arquivados. Isto ocorre porque não existe uma lei que criminaliza a transfobia (ANTRA, 2018).

\footnotetext{
${ }^{1}$ Designa como norma e como normal a atração e/ou o comportamento sexual entre indivíduos de sexos diferentes [...] normatiza modos de ser e de viver os desejos corporais e a sexualidade de acordo com o que está socialmente estabelecido para as pessoas, numa perspectiva biologicista e determinista, há duas - e apenas duas - possibilidades de locação das pessoas quanto à anatomia sexual humana, ou seja, feminino/fêmea ou masculino/macho (Petry \& Meyer, 2010).
} 
O Projeto Transexualidades e Saúde Pública no Brasil reuniu dados que mostram que muitos já passaram por algum tipo de violência, seja física, sexual, psicológica ou institucional, já que as agressões podem advir de familiares, amigos, vizinhos, colegas de trabalho, professores, colegas de sala de aula, policiais, líderes ou membros de religião, pessoas desconhecidas na rua, funcionários de locais públicos e comerciais. Há também sofrimento psíquico, pois, em relação a depressão, 20 (71,45\%) dos 28 (100\%) participantes declararam ter e/ou já tido a doença em algum momento, e 24 (85,7\%) já pensaram em suicídio e/ou tentaram cometer o ato (Souza, 2015).

Considerando essas vulnerabilidades e pensando na necessidade de assistência à saúde dessa população, observa-se a importância da crescente formação dos profissionais para a compreensão de suas particularidades e dos seus direitos que estão garantidos na portaria 2.836 de $1^{\circ}$ de dezembro de 2011 que institui no Sistema Único de Saúde (SUS) a Política Nacional Integral de Lésbicas, Gays, Bissexuais, Travestis e Transexuais (Ministério da Saúde, 2011), já que as pessoas trans são as que mais enfrentam dificuldades nos serviços públicos de saúde, tanto no "processo transexualizador"2, como em outros serviços de saúde específicos para essa população ou não através de discurso preconceituoso e desrespeito ao nome social, além de associação a uma patologia que necessita de um diagnóstico médico (Cassalha et. al, 2020). Isto ocorre pela existência da transfobia ${ }^{3}$ (Mello, et al, 2011).

Contudo, possibilitando a despatologização da população transgênera houve a retirada dos "transtornos de identidade de gênero" do capítulo de doenças mentais, da Classificação Estatística Internacional de Doenças e Problemas relacionados à Saúde (CID 11) utilizando no lugar, o termo "incongruência de gênero", no capítulo sobre saúde sexual, pois a OMS, considera que é preciso garantir atendimento às demandas específicas de saúde da população trans (UNAIDS, 2018).

Dentre as demandas específicas está a transição para a qual as pessoas trans estão apoiadas na portaria 2.803/2013 do Ministério da Saúde, que redefiniu o Processo Transexualizador no SUS e mantém como princípios das diretrizes de integralidade da atenção a transexuais e travestis, não restringindo ou centralizando a meta terapêutica às cirurgias de transgenitalização ${ }^{4}$ e em demais intervenções somáticas; com atendimento livre de discriminação da equipe interdisciplinar e multiprofissional, tendo como porta de entrada a Atenção Básica em saúde (Ministério da Saúde, 2013).

Além disto, após o decreto 8727 assinado em 2016 pela presidenta Dilma Rousseff, e a decisão do Supremo Tribunal Federal (STF), transgêneros podem alterar o nome e o sexo no registro civil sem que se submetam a cirurgia, atestando a identidade psicossocial através de autodeclaração em um cartório. Isto permite que garantam todos os outros documentos civis que advém desse, com o nome social (Presidência da República, 2016; STF, 2018).

Atualmente a transfobia é considerada crime após a decisão do Supremo Tribunal Federal (STF) que entendeu que houve omissão inconstitucional do Congresso Nacional por não editar lei que criminalize atos de homofobia e de transfobia. A corte considerou crime atos que ferem os direitos fundamentais da população LGBTQIAP+ realizando assim o enquadramento da homofobia e da transfobia como tipo penal definido na Lei do Racismo (Lei 7.716/1989) até que o Congresso Nacional edite lei específica. Com isso, as condutas homofóbicas e transfóbicas, reais ou supostas, se enquadram nos crimes previstos na Lei 7.716/2018 e, no caso de homicídio doloso, constitui circunstância que o qualifica, por configurar motivo torpe (STF, 2019).

A não-especificação, porém, de uma secretaria ou conselho do novo Ministério da Mulher, da Família e dos Direitos Humanos na Medida Provisória (MP) 870, do governo do presidente Jair Bolsonaro, conforme havia no governo anterior, mantém a população LGBTQIAP+ (Lésbicas, Gays, Bissexuais, Transexuais, Queers, Intersexuais, Assexuais, Pansexuais, etc)

\footnotetext{
${ }^{2}$ Processo pelo qual a pessoa transgênero passa, de forma geral, para que seu corpo adquira características físicas do gênero com o qual se identifica. Pode ou não incluir tratamento hormonal, e procedimentos cirúrgicos variados (Jesus, 2012).

${ }^{3}$ Preconceito e/ou discriminação em função da identidade de gênero de pessoas transexuais ou travestis (Jesus, 2012).

${ }^{4}$ Procedimento cirúrgico por meio do qual se altera o órgão genital da pessoa para criar uma neovagina ou um neofalo. Preferível ao termo antiquado "mudança de sexo" (Jesus, 2012).
} 
à margem, dependente de interpretações não explícitas conforme as outras especificidades populacionais presentes na MP interferindo assim em todas as instituições federais (Presidência da República, 2019).

Considerando todas essas questões de vulnerabilidade, a Terapia Ocupacional trabalha com as pessoas trans:

Se as experiências trans têm sido balizadas pela invisibilidade de uma possibilidade de viver com dignidade e se as formas de subjetivação, práticas e modelos de vida que lhe são impostos adotam como base os discursos hegemônicos heteronormativos, a Terapia Ocupacional deve amparar-se não somente nessas experiências para pensar estratégias de inclusão como também nos mecanismos que os reforçam, buscando a dimensão de uma prática que extrapole os limites do sujeito individual que dimensione a urgência de intervenções pautadas no coletivo, na estrutura e no trânsito social (Melo, 2016, p. 221).

Benetton (1994) relata que, em vez de enfrentamento ou do aplacamento de sintomas, na terapia ocupacional, propõese construir ou reconstruir cotidianos. Utilizando de atividades como instrumento terapêutico, com o propósito de criar elementos que promovam a expressão de sentimentos, a autoaceitação, a reorganização da capacidade práxica, além de auxiliar na busca de instrumentos que favoreçam a inclusão social.

Sendo assim, compreendemos as possibilidades de atuação da terapia ocupacional, tendo como objetivo geral desta pesquisa: compreender e relatar os impactos sociais e mentais das noções de gênero sobre as pessoas trans, por meio de atividades expressivas utilizadas no encontro de terapia ocupacional. Os objetivos específicos são: compreender as maiores dificuldades e/ou preconceitos enfrentados pelas pessoas trans na sua infância e na sociedade atual; entender o quanto as opressões sociais afetam sua saúde mental; e descrever a compreensão sobre família, amor e sua expectativa para o futuro.

\section{Metodologia}

Esta pesquisa foi realizada através de um encontro de terapia ocupacional envolvendo observação e análise do uso de atividade expressiva com pintura. Para Ballarin (2003), o tratamento, em um grupo de atividades em Terapia Ocupacional, ocorre com o fazer coletivo, e permite a reunião dos sujeitos com o terapeuta ocupacional para a realização de atividades como: pintar, passear, desenhar, modelar, dançar, fazer compras, costurar, entre outras, fazendo com que gere um ambiente confiável, possibilitando que o grupo funcione como uma caixa de ressonância, envolvendo o compartilhamento de sentimentos, a interação social, a comunicação verbal e não verbal.

Foi escolhida a abordagem qualitativa considerando que a pesquisa qualitativa dedica-se ao trabalho com valores, crenças, hábitos, atitudes, e adequa-se a aprofundar a complexidade de fatos, processos particulares e característicos a grupos e indivíduos. Sendo assim, é aplicada para compreender os fenômenos caracterizados por uma alta complexidade interna, não sendo algo simples descrito a partir de poucas leis universais (Minayo \& Sanches, 1993).

\subsection{Local da pesquisa}

O encontro foi realizado, na cidade de Aracaju, pois seria mais próximo para os sujeitos. O local escolhido foi a CasAmor, onde é desenvolvido um projeto sem fins lucrativos que busca abrigar e amparar pessoas LGBTQIAP+ (lésbicas, gays, bissexuais, transexuais, queers, intersexuais, assexuais, pansexuais, entre outros) sem lar e em situação de vulnerabilidade, pois poderia oferecer um ambiente acolhedor e seguro para os sujeitos, respeitando a importância do setting terapêutico. 


\subsection{População-alvo}

Foram convidadas pessoas trans que frequentavam a CasAmor e apresentaram interesse, pela importância de considerar a diversidade de classe social, raça, idade e escolaridade entre elas. O grupo ocorreu a partir da seleção de dia e horário em que uma maioria pudesse participar, tendo imprevistos e indisponibilidades compatíveis dos sujeitos, dificultando o dia do encontro, conseguindo realizar o mesmo com um grupo de duas mulheres trans e três homens trans.

\subsection{Aspectos éticos}

A principal questão ética dessa pesquisa refere-se à garantia de anonimato dos participantes através do uso de nomes fictícios, que deverá ser garantido em todas as publicações decorrentes da mesma, sendo compromisso assumido pelas pesquisadoras. A presente pesquisa, assim como sua execução, foi formalmente autorizada pelo gestor da instituição. Além disso, os sujeitos que aceitaram participar da pesquisa só iniciaram mediante assinatura do Termo de Consentimento Livre e Esclarecido (TCLE) em duas vias, ficando uma com eles e a outra com os pesquisadores. No TCLE estão explicitados os objetivos da pesquisa, a garantia do anonimato da identidade dos participantes e a forma de utilização dos dados provenientes da investigação.

A pesquisa foi autorizada pelo Comitê de Ética e Pesquisa da Universidade Federal de Sergipe sobre o número 02198818.7.0000.5546/3.017.473.

Os dados foram coletados por meio da realização de um encontro com os sujeitos utilizando de atividade expressiva com pintura, na qual todos os depoimentos foram gravados durante a realização das atividades e dos temas propostos e abordados no encontro. Os temas foram dados aos sujeitos, na qual eles fizeram todas as atividades e após a finalização destas, os mesmos trouxeram depoimentos sobre o que haviam feito e falaram outras coisas que sentiram necessidade.

Os temas propostos foram:

1. Como foi a infância?

2. O que é família para você?

3. O que seria preconceito para você?

4. O que é amor para você?

5. Qual seu sonho?

6. O que espera do futuro?

\section{Resultados e Discussão}

Para melhor visualização dos dados e resultados o conteúdo foi dividido de acordo com os temas propostos na atividade de pintura, no entanto, foram ao todo sete temas, já que durante a discussão os sujeitos solicitaram que fosse acrescentado o tema "sexo", relatando a extrema importância que envolve o assunto.

\section{$1^{a}$ Atividade - "Infância: uma verdadeira amnésia"}

Neste primeiro tema, os sujeitos abordaram suas infâncias como um momento traumático, na qual a solidão, o desprezo e a "não aceitação" dos outros estiveram muito presentes. A maioria prefere esquecer esse período como afirma Jaqueline que

Sempre que fala infância eu penso em amnésia, muita coisa travada, que eu não me deixo lembrar, reviver, porque foi traumática ...coisas triviais, que se apagaram, como uma forma de estratégia de proteção (Jaqueline). 
Na infância, me vejo muito sozinho, hoje percebo o quanto bloqueio as lembranças, coisas que eu não consigo mais acessar, de tão traumáticas que são, eu prefiro a obrigação de não dizer nada. (Luan).

Para Bento (2006) a infância é o momento em que os enunciados performativos são interiorizados como: "homem não chora", "isto não é coisa de menina". Estes acabam atrofiando sentimentos e comportamentos espontâneos, substituindo-os por performances no espaço público e familiar, pois se fizerem algo contrário do aceito pela sociedade podem ser excluídos, considerados errados ou estranhos, como foi notada na fala de uma participante, na qual ela sente que não se encaixa em nenhum lugar, como se realmente estivesse errada ou não pertencesse ao local em que se encontrava.

Minha casa era muito branca...isso me incomodava muito ...era uma família de pessoas brancas, que eu era negra ... eu chamei de "CasaÓdio", sendo o oposto de "CasAmor". .. tem uma placa de proibido, pois eu sou muito colorida, não me encaixava (Jaqueline).

Breno Rosostolato (n.d.), afirma que:

No caso de crianças transgêneras, a discriminação e o preconceito fazem com que esta que, não possui recursos e defesas construtivas, retraia-se e isole-se. Ela acaba se sentindo diferente, como um ser doente e anormal. Ela vai definhando e perdendo sua autoestima. Assim, fica vulnerável emocionalmente e propensa à depressão. $\mathrm{O}$ afeto vai se embotando e a criança fica sem referências positivas (n.d.)

Segundo Bento (2012, p. 275) mesmo antes de nascer uma criança já carrega toda uma carga profunda de expectativas no espaço público sobre como ser masculino ou feminina que lhe será atribuída no parto em função de ter um pênis ou uma vagina. Ou seja, a partir disso, desempenhos serão esperados e subentendidos com nexo causal precedente. "Aqueles que não cumprem com o programado rompem o pacto e são excluídos, ficando à margem da sociedade”.

Minha vida eu considero uma bagunça, bagunça de sentimentos, uma bagunça de relações, bagunça de tudo minha infância bagunçada, no sentido de eu ser excluído, de ter vários grupozinhos [sic] e eu não me encaixar em nenhum e ser excluído de tudo, ou me sentir excluído (Arthur).

Um grupo de muitas pessoas e eu no meio, excluído, rejeitado, sozinho, isolado... existia uma barreira entre mim e as outras crianças (Arthur).

Segundo Lanz (2014) a pessoa transgênera vive em angústia por romper com as regras heteronormativas e também por se esforçar para estar de acordo com elas no gênero com o qual se identifica.

A infância permanece uma confusão da minha mente, de ser quem eu achava que era ou do que as pessoas queriam ou achavam que eu fosse (Arthur).

As pessoas me enxergavam de uma forma, e internamente eu sentia que eu era totalmente diferente do que as pessoas me enxergavam, mas eu não tinha liberdade de expressão (Rodrigo).

Para melhor visualização de suas expressões serão dispostas as imagens de suas atividades: 
Figura 1. Atividades sobre a infância.
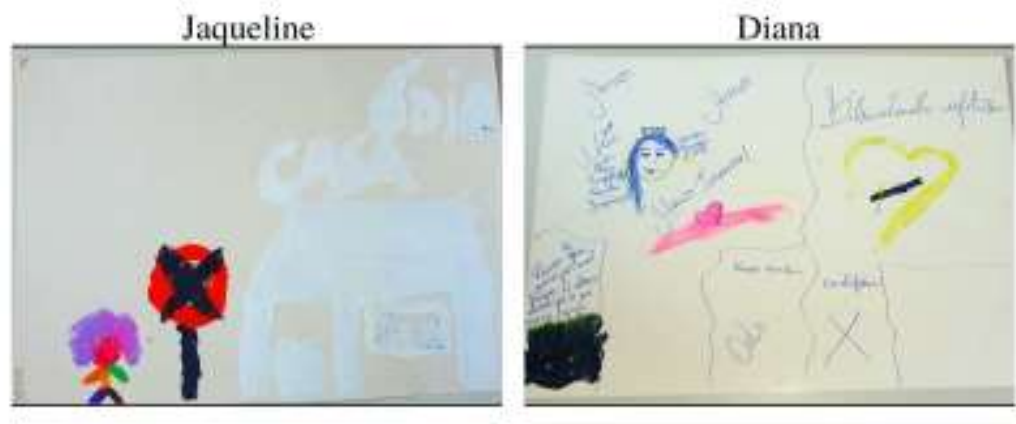

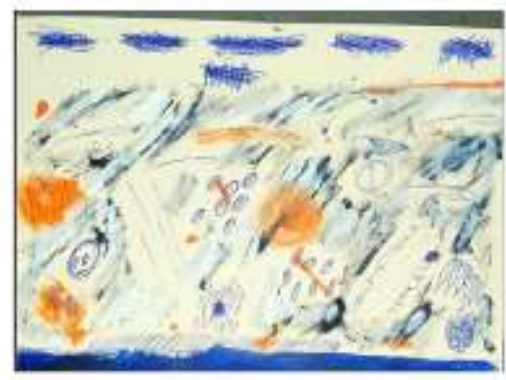

Arthur

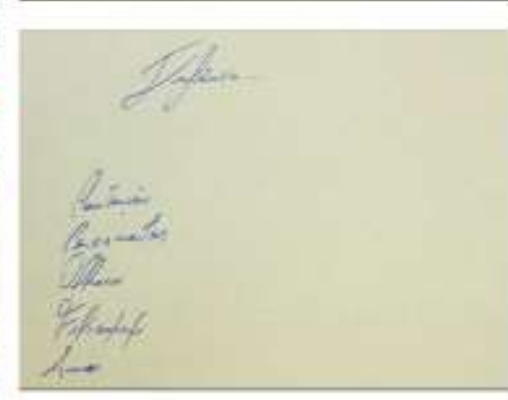

Rodrigo

Fonte: Arquivo Pessoal.

É possível observar que na atividade de atividade de Jaqueline existe uma casa branca denominada de Casa Ódio “em que ela era a pessoa negra, colorida e proibida" com estes elementos representados com uma placa de proibição e uma pessoa colorida. Já na atividade de Diana existem elementos e escritas que representam o abandono do pai, a pressão familiar, o ódio e a gordofobia, além da referência da vivência com sua mãe e sua necessidade de liberdade afetiva. A atividade de Arthur representa de maneira muito expressiva a bagunça que relatou viver de sentimentos, a exclusão, conflitos em pequenos grupos, tensão e poucos momentos felizes pintados em laranja. A atividade de Rodrigo é suscinta, resumindo sua infância em palavras como “contenção, pensamentos, olhares, felicidade, amor”. Neste tema Luan não realizou atividade.

\section{$2^{a}$ Atividade - "Família: uma palavra vazia"}

Neste tema os sujeitos trouxeram e descreveram de maneira muito importante, o sofrimento psíquico recorrente que vivem e viveram no ambiente familiar já que, na maioria das vezes, não são acolhidos e respeitados pela identidade de gênero. Ficou evidente na fala da maioria a enorme dificuldade que eles têm para se sentirem incluídos mediante a pressão e o sentimento de exclusão e não pertencimento ao grupo familiar que lhe foi conferido.

Era um impasse pra mim eu não podia ter uma liberdade afetiva com tantos conflitos que eu tinha na minha família ...eu coloquei pressão familiar e ódio e não desenhei nada para eles, porque eles não são nada pra mim (Diana).

Como eu iria me encaixar com a minha transexualidade é impossível conviver ... pra nós é difícil estar em alguns lugares, realmente incomoda, os olhares, a forma como as pessoas nos tratam, eu não me encaixava (Luan).

Para Olson, Forbes e Belzer (2011) a família têm um papel fundamental na vida de transgêneros, aquelas que apoiam e protegem evitam os resultados negativos e ajudam a promover a saúde positiva e bem-estar; enquanto que, as famílias que rejeitam afetam-os negativamente e contribuem para aumentar os seus problemas de saúde e os seus estados de saúde mental. 
$\mathrm{Na}$ fala de três sujeitos foi possível observar que eles conseguem compreender e enxergar o que é a família e a importância que esta tem para cada um, no entanto, trazem que é algo realmente vazio para eles, pois não tem essa definição ainda, talvez por não ter essa convivência, ou não terem recebido o que acreditam ser necessário.

É onde a gente se sente em casa, onde tem amor em cada gesto e em cada ação. É acolhimento e compreensão. É o que eu nunca tive de quem tem meu sangue correndo nas próprias veias, pulsando (Rodrigo).

A família das outras pessoas, seria como uma família deve ser de fato, todo mundo juntinho, como um grupo de verdade, todo mundo se apoia, se conhece, se ama, mas na minha família, todo mundo é separado, cada um no seu canto ...é apenas um grupo de pessoas que moram no mesmo lugar e quase não sabem nada um do outro, cada um vive a sua vida isoladamente (Arthur).

Nunca tive uma família da maneira como foi proposta para ser ...lugar de suporte, companhia, carinho, amor, para você ser fortalecida na vida e conseguir lidar com o caminhar, meu problema da vida já começava na família...meu sonho era me desvencilhar completamente da minha família, não tenho nenhum sentimento positivo para nenhum deles, então não tem porque eu interagir, manter relações, tentar reconstruir algo em nada, já que isso era uma responsabilidade deles no momento em que eu nasci e eles nunca tiveram ou quiseram, sempre permaneceu o desprezo e a rejeição por mim ... (Jaqueline).

Para Lanz (2014), é na família que as pessoas transgêneras sofrem as primeiras violências, discriminações e estigmatizações sendo reprimidas e excluídas acreditando "que estão fazendo uma coisa errada". Quando a criança se comporta com uma imagem semelhante ao outro gênero a família se torna agressiva.

Os participantes desta pesquisa trazem, portanto, que a família é algo realmente vazio, quando vindo das pessoas consanguíneas, necessitando criar outros conceitos de família, ou novas famílias como amigos por exemplo.

Machuca, ter várias famílias e não ter nenhuma, chegar época do natal, ano novo, aniversário e aí todo mundo vai para algum lugar ... família é importante ... e eu aceito isso e entendo, parte da minha família mora muito perto da minha casa, eles fazem festa, se reúnem, se juntam pra conversar, praticamente todo domingo ... eu vejo no instagram que todo mundo tem uma família para datas comemorativas e de certa forma, eu não tenho, então não tem desenho, eu não tenho definição de família, família é algo vazio ainda pra mim (Diana).

Quando o povo me pergunta se tenho família eu falo que não ...minha família são os meus amigos, são as pessoas que eu encontrei na vida, que conseguiram me aceitar da forma que eu sou (Diana).

Facilitando o entendimento da discussão, serão dispostas as imagens de suas atividades: 
Figura 2. Atividades sobre a família.
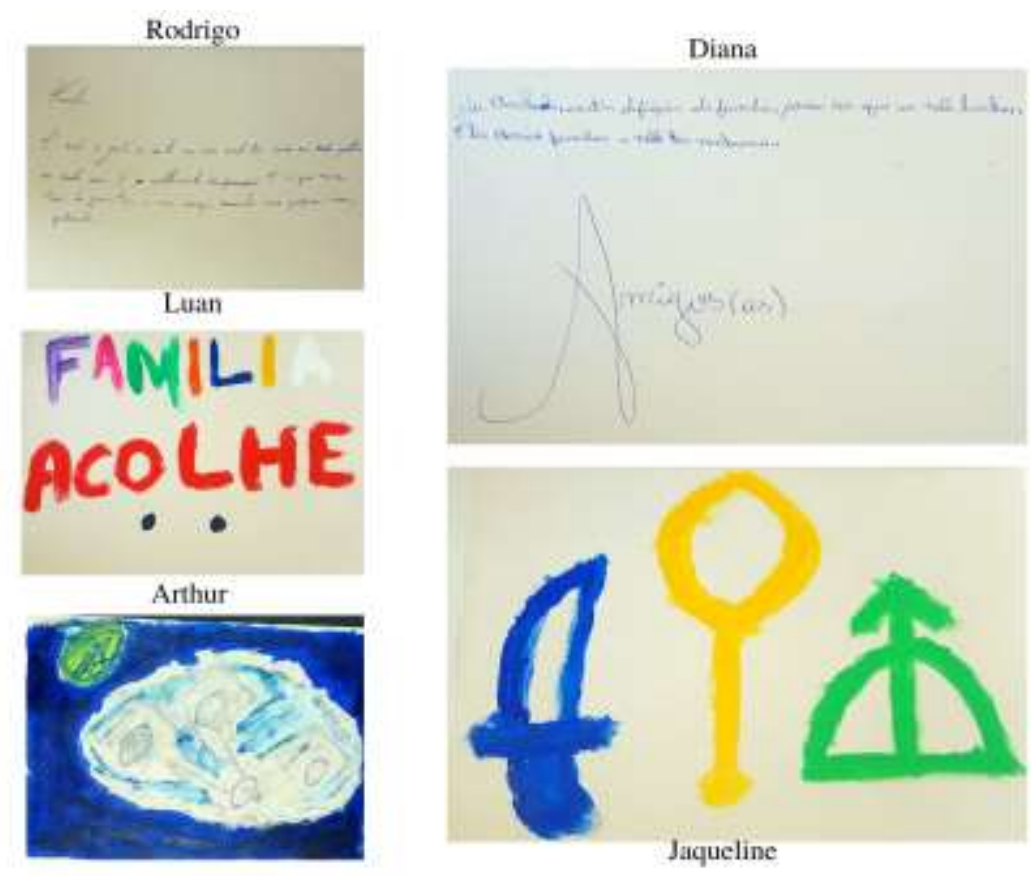

Fonte: Arquivo Pessoal.

A atividade de Rodrigo é exatamente a sua fala em grupo de que o comportamento esperado de família representa o que ele nunca recebeu de seus parentes. Diana resume sua família aos amigos já que também não considera seus parentes como família. A atividade de Luan expressa a sua visão de família em contraponto ao que recebe da sua. Arthur representou pessoas afastadas sem comunicação e apoio entre si como relatou visualizar sua família. Jaqueline por sua vez trouxe símbolos do candomblé, por considerar que encontrou sua família nos amigos da religião.

\section{Atividade - "Preconceito: um Brasil que sangra"}

Diversos estudos intensamente difundidos como os de Pelúcio (2009), Peres (2005) e Carrara e Vianna (2006) demonstram o constante processo de marginalização e preconceito por parte da sociedade como um todo e de diversos setores sociais, tais como saúde, educação e segurança pública.

Para Lanz (2014), o problema é e está na não constituição de uma categoria de gênero para assim reconhecer essa população. A não abertura para o novo acaba frustrando a sociedade de tal forma que acabam não acolhendo o público transgênero, onde muitos acabam vivendo a parte de suas vidas, excluídos de seus próprios direitos enquanto cidadãos, sendo submetidos a todo tipo de constrangimento diante das situações mais comuns do dia a dia, como piadas, xingos e até mesmo violência física. Cicatrizes que levam muitos a procurarem o suicídio para assim não viver em um mundo onde eles não possam expressar seu eu e viver como deveria ser.

Lembro de uma vez, que eu estava indo para casa... e eu um corpo estranho né? Vieram dois homens numa moto, um desceu, me deu um soco, pegou minha bolsa, depois me olhou, começou a rir ... eles me atiraram no solo e começaram a me arrastar, uns cinco metros, rolando ... essas situações acontecem todos os dias, com muitas pessoas trans (Luan). 
Foi o que eu sofri por anos a cada dia que passa, cada minuto e segundo. Foram todas as palavras que ouvi e me silenciei diante delas. Foram os xingamentos, os julgamentos, foi e é o medo que tenho de ser eu mesmo, de me expressar e simplesmente de ser eu (Rodrigo).

Ter o direito de viver como se quer, é uma questão defendida por lei e faz com que repense a incapacidade de compreender aquilo que foge às regras e aos padrões.

O direito à vida, à integridade psicofísica e à saúde constituem o trinômio que informa o livre desenvolvimento da personalidade e a salvaguarda da dignidade da pessoa humana. Esse princípio é determinante em qualquer questão de biodireito, estando previsto no artigo $1^{\circ}$, inciso III, da Carta Magna, como um valor fundamental sobre o qual se funda a República. $\mathrm{O}$ direito à busca do equilíbrio do corpo-mente está ancorado no direito à saúde e no direito à identidade sexual que integra um aspecto da identidade pessoal (Bunchaft, 2013, p. 283).

Segundo Gonçalvez (2009) o que dificulta a vida das pessoas trans é a falta de compreensão da sociedade pois se houvesse apoio emocional seria mais fácil viver com qualquer identidade de gênero ou orientação sexual.

Costumo dizer que antes eu sentia muita raiva das coisas, só que conforme o tempo foi passando eu deixei de sentir raiva e tristeza para sentir só tristeza, preconceito é uma das coisas que mais me deixa triste, ele divide, segrega, faz você sangrar, se machucar e desconstrói, ele é essa coisa preta ... não merece ser descrito por cor, cor é uma coisa positiva e bonita, coisa que o preconceito não é ... é um dos piores lados do ser humano, ele mata, ele faz uma coisa bonita virar sangue, sofrimento, virar tristeza e ele prende as pessoas, tanto as pessoas que sofrem preconceito, quanto as pessoas que criam preconceito ... (Arthur).

Segundo a ONG Trangender Europe (TGEu) publicou em novembro de 2016, que o Brasil matou cerca de 868 travestis e transexuais nos últimos oito anos, estando em primeiro lugar no ranking de países com mais registros de homicídios de pessoas transgêneras, sendo mais que o triplo de assassinatos do segundo colocado, o México. Isto, considerando a dificuldade em registrar casos subnotificados ou escondidos, e classificar as mortes como casos de transfobia, quando não é criminalizada (Balzer et al., 2016).

Preconceito é tudo de ruim, não existe nada bonito ... a gente passa na rua e ninguém chama a gente de bonita, ninguém diz que a gente está com uma boa autoestima ou que a gente está com uma roupa legal, dizem logo que a gente é aberração, e que é feia, e que devia morrer ... muitas são mortas como já foram e que vão continuar sendo mortas (Diana).

Desenhei a bandeira do Brasil com vermelho no lugar do verde e respingos de vermelho, porque quando eu penso no que eu passo de discriminação por ser travesti preta, que são as minhas marcas da sociedade, eu penso em Brasil e como a culpa é do Brasil, de como o Brasil foi construído, de como o Brasil me deve muito quanto cidadã ... eu nunca fui e nunca serei e as que são iguais a mim também nunca foram e nunca serão cidadãs brasileiras. Nunca experimentamos brasilidade, a gente sempre foi um ser abjeto que nunca nos quiseram aqui e o Brasil foi e é projetado para uma higienização da travesti, da preta, é tipo tirar elas das ruas, da sociedade e se tornar um ser abjeto que nem tem valor de existência ... por isso o Brasil tem muito sangue nas mãos (Jaqueline).

Para Lanz (2014), as pessoas transgêneras querem apenas existir, viver e trabalhar como pessoas absolutamente comuns, andar pelas ruas sem serem julgadas ou agredidas. Sua maior e mais importante reinvindicação - senão única - é serem compreendidas e aceitas como pessoas comuns e normais.

O preconceito é uma mancha na sociedade, que culpa não só quem faz, como a gente que se sente culpada, muitas das vezes eu me sinto culpada por ser quem eu sou, e não só eu, mas como várias outras pessoas se sentem culpadas 
por ser quem elas são... mas tenho uma esperança de que um dia a gente possa passear nas ruas como pessoas normais ... tenho esperança de que a sociedade um dia ainda vai mudar e que vai nos aceitar ... (Diana).

Para melhor compreender suas vivências seguem as imagens de suas atividades:

Figura 3. Atividades sobre o preconceito.
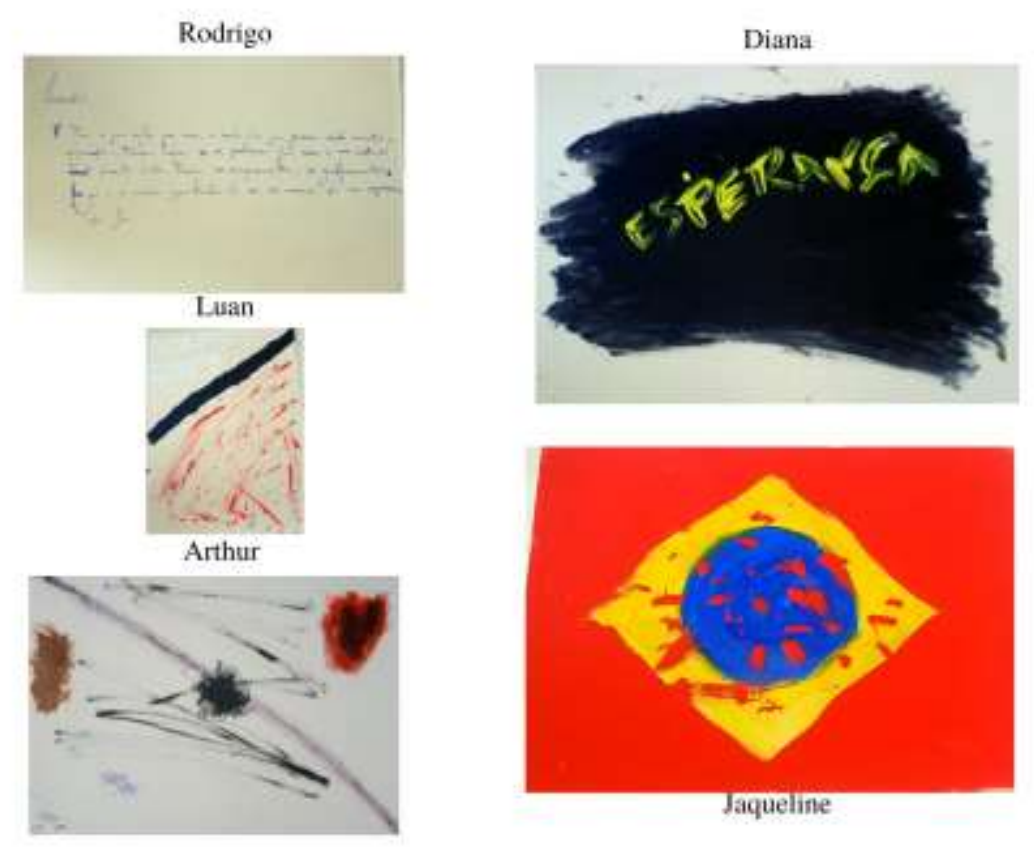

Fonte: Arquivo Pessoal.

A Atividade de Rodrigo traz sua fala representada por discriminação, medo e silenciamento. A atividade de Diana representa o preconceito através da cor preta e a esperança de melhora na sociedade através da palavra escrita em amarelo, trazendo cor à escuridão vivida. A atividade de Luan representa a violência que sofreu em vermelho representando sangue e a falta de sentimento de culpa advinda dos agressores através da frase "a culpa cospe". A atividade de Arthur traz expressividade através de pontos relatados em sua fala como tristeza, segregação, morte, sofrimento e sangue. Jaqueline oferece à este tema uma bandeira do Brasil em vermelho representando o sangue e o sofrimento que impede a cidadania das travestis.

\section{4" Atividade - "Amor: algo que não merecemos"}

O tema amor foi trazido de diferentes maneiras, como: sendo as coisas simples do dia a dia, a liberdade, o estar sozinho, sexo, alguém em específico, o tudo e o nada, no entanto, também foi trazido como algo que a maioria não sabe se já vivenciou, se ainda vão conseguir vivenciar, ou mesmo, se são merecedores deste sentimento.

Tenho uma visão diferente de amor, não é nada muito romântico ... são as pequenas coisas que não damos importância no nosso dia a dia: o cheiro do café, ou então uma pergunta: Como foi seu dia? É reciprocidade, compreensão, é uma música que você bota, você gosta, e você fica bem ali sozinho, você estar sozinho não quer dizer que não tenha amor (Rodrigo).

Amor é liberdade, é se sentir em casa, é ficar bem, mas eu também não tenho muitas definições de amor não. Amor ainda é um tanto vazio. A gente não recebe muito amor para dar muito amor ... o amor é tudo, é nada, é sexo (Diana) 
Amor é tudo, mas também é nada e eu não sei se eu já experienciei amor, mas eu também já falei te amo várias vezes... não sei se vou experienciar amor algum dia, se na verdade eu sou merecedora de amor, porque amor foi construído de uma forma tão engessada, que não é permitida essa liberdade para que a gente seja amada, para que todas as pessoas sejam amadas (Jaqueline).

A abjeção, “opera como lugar da não aceitação do que é considerado monstruoso, odiado, vomitável, infame e anormal ao ameaçar os padrões controláveis e previsíveis” (Silva \& Silva, 2013, p. 63). Por isso, foi possível observar na fala acima que o sujeito traz que talvez ele não seja nem mesmo merecedor do amor.

Quando indivíduo não experiencia afeto e amor da família e das instituições sociais, ele pode visualizar uma perspectiva de futuro resumida em alguém, enquanto um sonho, conforme relato:

Fiz os últimos três: amor, futuro e sonhos. Porque eu fiz os três juntos? ... porque para mim, meu futuro, meu amor e meus sonhos, é minha esposa ... ela que me mantém vivo hoje no meio de tanta desgraça, ela é o pontinho de cor na minha vida (Arthur).

Facilitando a visualização de suas expressividades seguem as figuras:

Figura 4. Atividades sobre o amor.

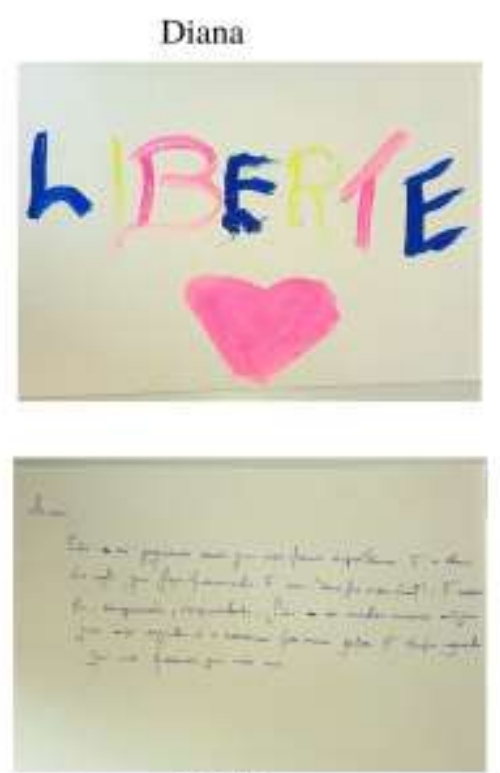

Rodrigo
Jaqueline
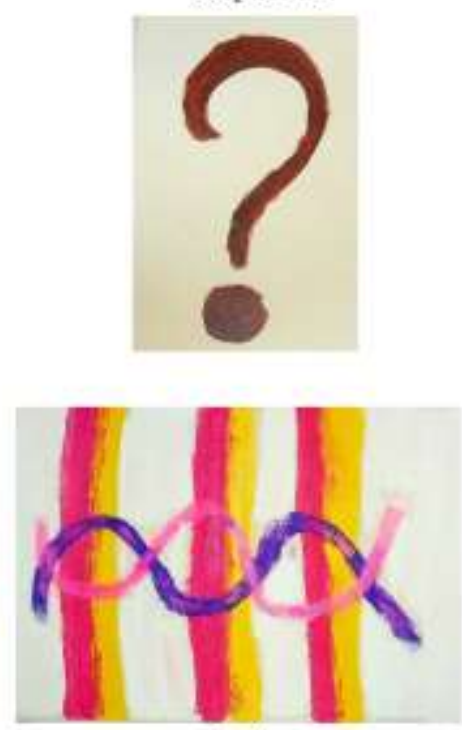

Arthur

Fonte: Arquivo Pessoal.

Para Diana, amor é liberdade e é vivenciado de diversas maneiras que ela representou através das cores azul, amarelo e rosa. Atividade de Jaqueline representa a dúvida através da interrogação. A dúvida sobre o conceito de amor, sobre a vivência dele, sobre o merecimento e a reciprocidade. Rodrigo traz em sua atividade seu relato sobre amor se resumir a vivências prazerosas sozinho ou acompanhado. Arthur por sua vez retratou amor, sonho e futuro em uma só atividade resumindo todos os temas à sua esposa, e para isso representou linhas infinitas e entrecruzadas em rosa, roxo e amarelo. Luan não realizou pintura nesta atividade. 


\section{Atividade - "Sonho: a luta pela existência"}

A questão da alteridade ${ }^{5}$ é um fator crucial, pensando na diferença, que ainda constitui como uma problemática de proporções históricas, econômicas e culturais de importância na vida comunitária e coletiva. A maioria das relações sociais com pessoas cis geram situações de medo e exclusão. Portanto, nas falas dos sujeitos o sonho trazido foi o desejo de serem aceitos, sem rótulos e assim, conseguirem viver uma vida "normal".

Batam palmas para as travestis que lutam para existir. Eu acho que de tudo que eu já sonhei, o mais importante é um mundo que a gente possa viver em paz, viver de boa e que as travas sejam travas e que pessoas sejam na verdade pessoas. Que não tenham rótulos, e que não existam barreiras para poder dizer: Fulano é isso e Ciclano é aquilo ou é Cis, ou é trans. Eu só quero isso (Diana).

Louro (2001) afirma que a inclusão no mercado de trabalho é distante para a população "LGBTT” pelos empecilhos colocados, sendo mais difícil de aceitação a inserção de transgêneros por carregarem no corpo a imagem que distorce a binaridade padronizada pela sociedade.

Basta uma rápida olhada nos anúncios de emprego para deixar claro que o mercado de trabalho possui uma estrutura segmentada pelo gênero-definido pela dicotomia convencional homem/ mulher. Muitos valores subjetivos e avaliações estão embutidos nesta divisão- sobre aquilo que um homem ou uma mulher pode ou deve fazer. Pessoas com uma ambiguidade de gênero poderiam causar confusão e sentir rejeição, por não se encaixarem facilmente nos nichos que existem no mercado de trabalho. A mesma ambiguidade pode ser vista como algo capaz de perturbar o desempenho da função, principalmente num mundo onde muitas ocupações se exercem vinculadas à apresentação e conservação da imagem (Adelman, 2003, p. 83-84).

E isso pode ser visualizado no relato:

Estou desempregada há um século e não tenho previsão de arranjar um emprego tão cedo, a discriminação é muito presente, meus corres são todos clandestinos, por fora do formal e aí eu quero fazer isso com a minha arte, com o que eu amo fazer, que são as minhas poesias e música (Jaqueline).

De acordo com Ávila (2014), o sentimento de sua identidade de gênero não concordar com sua anatomia, manifesta uma exigência compulsiva, imperativa de "adequação sexual”, face à uma incompatibilidade daquilo que são anatomicamente e aquilo que sentem ser.

O corte [mamoplastia masculinizadora], acho que é o único sonho, não tenho muitos sonhos, porque tem muita frustração e aí eu prefiro viver o presente (Rodrigo).

Sendo assim, a necessidade de efetivar a transexualidade é evidente, na fala deste sujeito quando refere-se à mamoplastia masculinizadora ${ }^{6}$ para retirar os seios que não lhe permitem ser o homem que realmente é, sem necessariamente ser identificado como uma pessoa trans, tendo o privilégio de passabilidade. Segundo Pontes e Silva (2018, p. 407) “a passabilidade, implicada em uma performatividade de gênero, dispõe um conjunto de atos regulados e repetidos que asseguram uma imagem substancial de gênero no registro de uma matriz heterossexual e cisgênera".

\footnotetext{
${ }^{5} \mathrm{O}$ seu conceito como utilizamos hoje, substantivado, tem sua origem grega e significa diferença, diversidade. De uma forma ontológica compreende a condição de um ser distinto de outro no seu modo de ser específico ou no seu fato de ser numérico, isto é, na sua essência ou na sua existência: contrapõe-se a identidade de um ser consigo mesmo (Hames, et al., 2008).

${ }^{6} \mathrm{O}$ termo "mastectomia bilateral", quando empregado para os trans-homens, é inapropriado, porque a mama não é totalmente removida e mantém-se o mamilo. "Mamoplastia masculinizadora" seria o termo correto, porque se trata de uma readequação de tórax (Nery; Maranhão, 2015).
} 
Facilitando o entendimento de seus relatos serão dispostas as imagens de suas atividades:

Figura 5. Atividades sobre sonho.

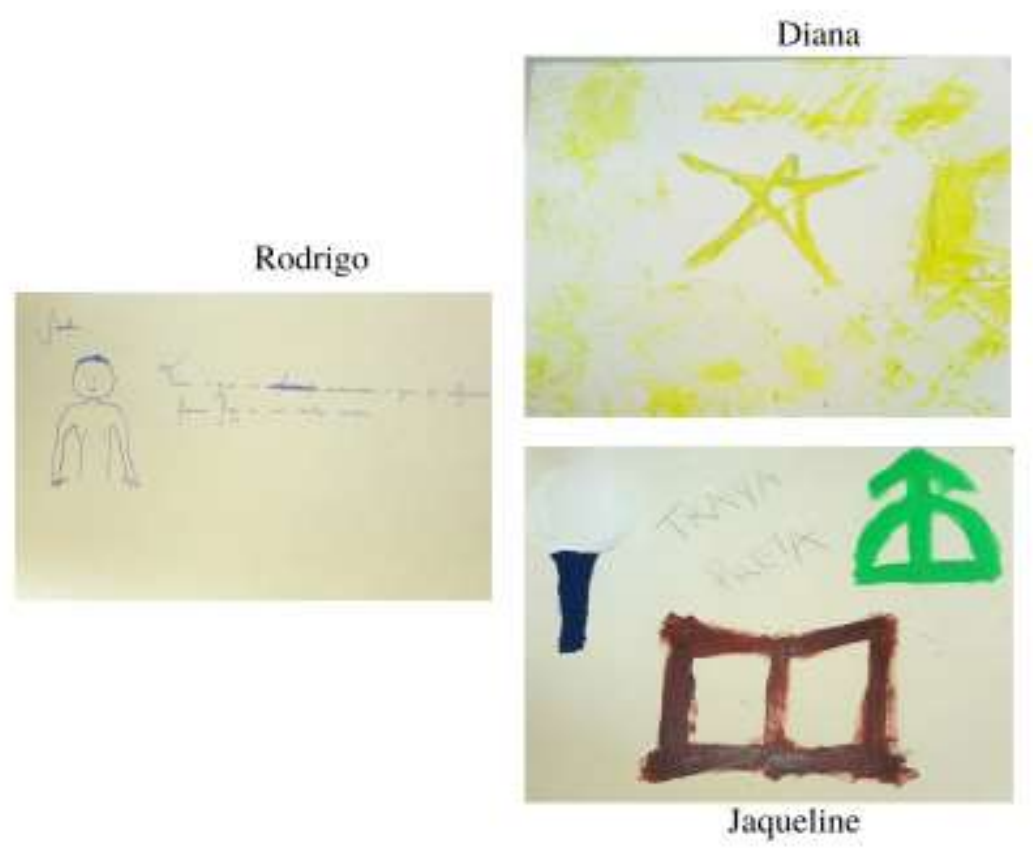

Fonte: Arquivo Pessoal

Rodrigo realizou um desenho de si com a cicatriz da mamoplastia escrevendo ao lado a frase "tirar o que me incomoda. O que de alguma forma faz eu me sentir menos" apresentando a relação direta de sua imagem com sua auto-estima. Diana representou uma estrela que relatou desejar ser com seu trabalho na dança mas também desejou que as pessoas pudessem ser quem são sem preconceitos. A atividade de Jaqueline traz símbolos como o microfone, o livro e outro símbolo do candomblé representando sua espiritualidade ligada ao desejo de viver de poesia e música.

\section{6a Atividade - "Futuro: Não sei se vivo ou se só tenho a experiência de sobrevivência"}

Foi possível perceber nas falas a dificuldade que os sujeitos sentem em se adequar na sociedade e de serem aceitos, apesar da força, da luta e principalmente da esperança de mudança. Segundo Viviane (2014) a pessoa transgênera está em um corpo não compreendido pela comunidade heterocisnormativa sendo vista como curioso, perverso, abjeto, transtornado e desumano.

Eu amo o lilás, pois é neutro, nem rosa e nem azul ... eu fiz um coração trans, porque mostra toda essa travestilidade que eu acho que ainda tem pro futuro e que a gente ainda pode levar ... aí eu fiz uma caixinha com rótulos, mas não é bem uma caixinha com rótulos, porque tem esses amarelos que é pra mostrar que não existe só o rosa e o azul, existe o amarelo também que é a gente, que ele sempre sobressai a qualquer outra cor ... e algumas coisas que eu quero pro meu futuro que é minha faculdade que é algumas coisas que eu quero investir: na música, na dança, em outras coisas que eu penso também. Ter um futuro promissor, que toda travesti merece ter, entendeu? E que as pessoas não imaginam pra gente e que as pessoas não acham que a gente vai ter (Diana).

Segundo relatam ativistas do Brasil e da América Latina, a expectativa de vida das travestis e das mulheres trans é de 35 anos (Bortoni, 2017). Considerando que a média nacional brasileira, segundo dados do IBGE é de 75,5 anos, a falta de 
perspectiva das pessoas trans em um país violento é evidente. A necessidade de viver cada minuto por não saber ser estará vivo logo em seguida é expressa, pois o futuro pode ser breve.

Escrevi vida e eu botei o A meio apagadinho de propósito, porque apesar de eu emanar toda força e agressividade. Essa resistência que eu sei que eu emano, mas nem tudo é flores e eu me sinto aflita todos os dias, sem ao menos saber se eu vou ter perspectiva de vida um dia, se eu realmente vou desfrutar o que é uma vida plena, com os direitos de lazer ... sem as aflições que a gente passa todos os dias, só de acordar e saber que vai ter que passar da porta e vai estar com outras pessoas, porque a vontade é ficar naquela porta, mas para estar ali dentro você precisa de grana, no entanto, ninguém quer te ver na rua ... então para o meu futuro eu penso muito em ter uma vida, ter perspectiva de vida, mas eu coloquei mais na intenção se algum dia eu vou desfrutar do que é vida, com um A repleto de sangue mesmo ... não sei se vivo ... ou só tenho a experiência de sobrevivência (Jaqueline).

Objetivando a melhor compreensão de seus relatos seguem imagens de suas atividades:

Figura 6. Atividades sobre o futuro.
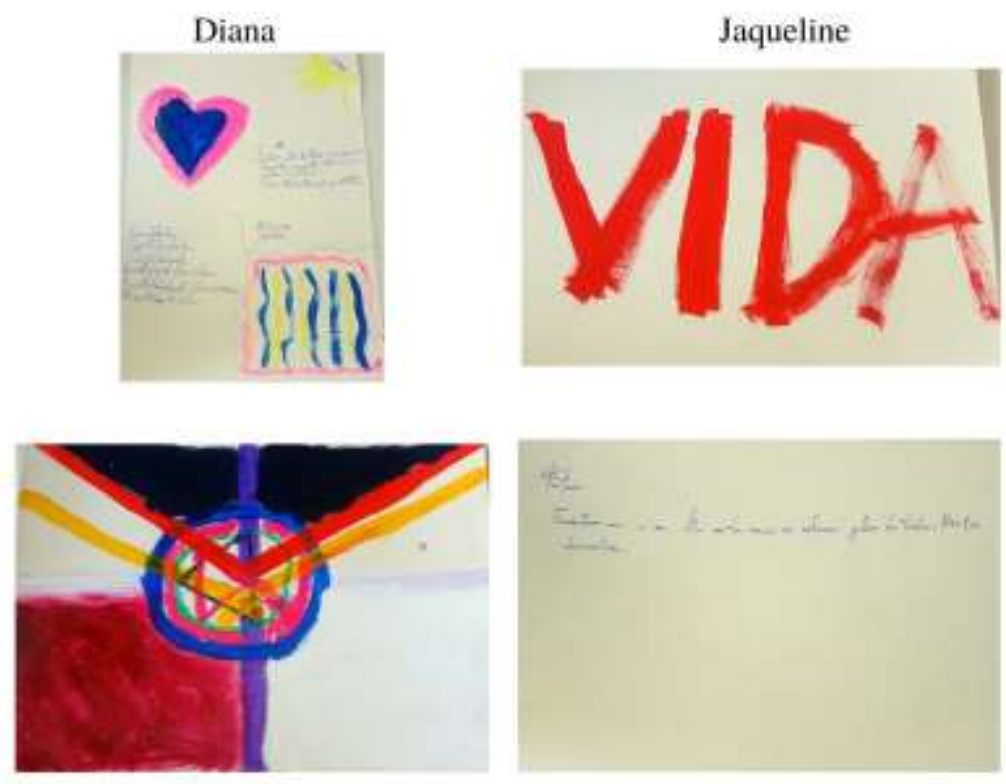

Rodrigo

Fonte: Arquivo Pessoal.

Diana traz em sua atividade elementos que representam sua faculdade, viver de música, dança e um amor. A atividade de Jaqueline representa um grande desejo de viver com direitos e oportunidades. Luan representou entrecruzamentos de experiências, boas e ruins sem visualização do "fim das linhas". Rodrigo retratou seu desejo de sentir-se pleno "encontrar-me e ser. me sentir como se estivesse pleno de tudo. não ter dúvidas.”.

\section{Atividade - "Sexo: uma máquina que não fala e não sente"}

Este foi um tema que surgiu do interesse e necessidade que os sujeitos demonstraram, enquanto um assunto que sentem necessidade de falar, de expressar, pois traz muita dor e sofrimento, já que normalmente não encontram espaço para isso. Segundo Jesus (2000) o termo "sexualidade" ainda carrega mitos e crenças de gerações mais antigas. O que representa um verdadeiro atraso frente a um tema tão relevante, carente de clara discussão também, com a população trans. 
Porque a gente não discute sexo? Porque a gente não se abre e fala exatamente como a gente gosta de sexo? Porque não é a forma como esperam sexo? Então se a gente quer desfrutar um bom sexo, porque a gente não abre a boca e fala? (Jaqueline).

Gherpelli (1996) considera que a sexualidade engloba o corpo e suas características físicas e hormonais que se relacionam com os desejos, assim como estão ligados às questões psicológicas, de autoestima, de descoberta de si e do outro, de concepção de intimidade, de ato sexual, afeto, entre inúmeras questões que interferem. Com isso, traz a ideia de que a sexualidade é maior que o coito e a procriação.

Na fala abaixo é possível observar a indignação de um sexo como algo mecânico, sem sentimentos e troca de intimidade um com o outro:

Somos simplesmente uma máquina de fuder e de chupar ... a maioria das vezes nem beija sua boca ... não chega nem perto do seu pau, como se eu não tivesse um pau e você não sente prazer através do seu pau, porque você tem que ser o espectro de uma mulher, então vou fingir que você não tem pau, e se tiver com a "neca" escondidinha, tapada com durex, melhor ainda, para só olhar o que importa que é o buraco ... temos que ser a representação exata do outro sexo (Jaqueline).

A exploração do sexo se torna dificultada, quando a sociedade tem dificuldade de separar a orientação sexual da identidade de gênero, assim como esclarece Jesus:

Uma pessoa trans pode ser bissexual, heterossexual ou homossexual, dependendo do gênero que adota e do gênero com relação ao qual se atrai afetivossexualmente: mulheres transexuais que se atraem por homens são heterossexuais, tal como seus parceiros; homens transexuais que se atraem por mulheres também o são. Já mulheres transexuais que se atraem por outras mulheres são homossexuais, e homens transexuais que se atraem por outros homens também. Não se pode esquecer, igualmente, das pessoas com orientação sexual bissexual (Jesus, 2012, p. 12- 13).

Essa dificuldade pode ser visualizada no seguinte relato:

Fico impressionada como a gente consegue quebrar uma barreira tão grande que é transicionar de um gênero para outro, mas não consegue acessar sexo e a gente não transa como a gente quer transar, porque eu sou travesti e eu sou bissexual ... me relaciono independente do gênero da pessoa, só que eu só transei com homem cis e trans, até hoje nunca transei com mulher, nem cis, nem trans. Primeiro porque: Mulheres não esperam receber afeto de uma travesti ...como se a travesti não vai querer outra buceta só vai querer se relacionar com um pau. Travesti é falocêntrica, travesti gosta de dar o cu ... isso é muito ruim e traz sofrimento (Jaqueline).

Segundo Judith Butler:

Os transexuais afirmam amiúde uma descontinuidade radical entre prazeres sexuais e partes corporais. Muito frequentemente o que se quer em termos de prazer exige uma participação imaginária de partes do corpo, tanto apêndices como orifícios, que a pessoa pode de fato não possuir, ou, dito de outro modo, o prazer pode requerer que se imagine um conjunto exagerado ou diminuído de partes (Butler, 2003, p. 108).

Não foi realizada atividade expressiva sobre o assunto, apenas discussão.

\section{Considerações Ffinais}

Este trabalho foi realizado a partir de uma percepção da primordialidade de expor e debater um tema tão necessário no ambiente acadêmico, acerca das necessidades e particularidades da população trans. Sendo assim, considerando que, apesar de os temas abordados terem sido amplos para interpretação, remeteram em todos os casos à discriminação sofrida por essas 
pessoas, o que insinua que vivenciam "esse drama" a todo momento e em quase todas as situações. Isto oferece a reflexão do quanto é difícil para elas viver em sociedade sem ter receio em adentrar ambientes, comunicar-se com outras pessoas ou até mesmo relacionar-se com elas, a ponto de sonharem com um futuro sem preconceitos para que possam existir sem apontamentos e sem o medo de ser mais um dado de estatística de assassinato (se for contabilizado).

O refúgio nas amizades e nos amores se apresenta como um retrato de uma vida repleta de exclusões, que fazem com que pessoas com vivências semelhantes, se compreendam e desejem viver em conjunto, ofertando apoio uns aos outros, formando novas famílias.

Além de todas estas questões, abordar o tema "sexo" sem tabu aparece como uma demanda evidente desta população pois se vivenciam desde a infância dúvidas e relações conturbadas com os corpos por identificarem-se com o outro gênero, originando desejo de transicionar e por sua vez, passar pelo processo transexualizador que oferta mudanças de hormônios e caraterísticas corporais, sofrem inferências diretas no ato sexual. O que não quer dizer, conforme relato de uma participante, que não sintam prazer com determinados órgãos sexuais considerados do gênero "oposto" ao qual se identificam. Estas questões, porém, necessitam ser abordadas principalmente por pessoas que possam se relacionar com trans gêneros.

Compreende-se também, que a sociedade brasileira é corresponsável pelas situações de constrangimento, traumas e violência (que por vezes finda no adoecimento físico e mental) que estas pessoas vivenciam, pois mantém uma cultura preconceituosa que embasa todos os ambientes e instituições, fazendo com que se perpetue o desrespeito e a falta de empatia. A elucidação social sobre o tema, porém, pode ser fundamental para solucionar este problema, através da educação (nos ambientes escolares e acadêmicos), da expressão cultural (como teatros, saraus e slams), e das mídias (como programas de televisão, novelas e rádio), pois, espera-se que ao ser exposto, elucidado e debatido, haja o desenvolvimento do respeito e da compreensão desde a infância, na família das pessoas trans, nas vizinhanças, nas escolas, e nos demais ambientes sociais. No cenário político, por exemplo, como câmaras e senado, deveria haver a criação de políticas públicas de inserção e proteção social, como bolsas permanência para as universidades, já que por vezes deixam de frequentar ambientes escolares ou não possuem apoio da família e necessitam trabalhar para se sustentar desde cedo; ou mesmo a aprovação da criminalização da transfobia enquanto lei com especificidades que não permitam brechas para reconhecimento da discriminação e também da punição aos responsáveis, sendo assim essencial para a redução da discriminação, por coibir atos de violência perante a proteção e garantia do estado.

Por fim, este estudo permitiu visualizar as dificuldades vivenciadas por esses sujeitos transgêneros, em meio à não compreensão e imposição da normatividade binária dos gêneros na sociedade, considerando que possuem especificidades que permitem interpretações diversas de feminilidade e masculinidade, não necessitando serem encaixadas em conceitos restritos da binaridade cishéteronormativa, que por sua vez sofre influência do patriarcado e do machismo estrutural.

A terapia ocupacional, portanto, carece de conhecimento do contexto desse recorte populacional para que haja base para atuação profissional nos campos de saúde mental ou nos contextos sociais, podendo atuar com a promoção da autonomia desses sujeitos, auxiliando no cotidiano, na convivência com a sociedade e ressignificando as suas experiências de vida, para que os impactos negativos das dificuldades enfrentadas possam ser amenizados e que possa haver o desenvolvimento de uma qualidade de vida.

É importante que os profissionais e a comunidade acadêmica se comprometam com a inserção da diversidade de gênero e sexualidade nos planos de aula, nos estágios e vivências escolares e universitárias por considerar a existências dessas pessoas em todos os ambientes sociais. Produções científicas com vivências dissidentes explicitando suas necessidades perante as classes profissionais e a atuação profissional que compreende, respeita e garante atendimentos qualificados à essa população precisam ser publicados para que haja a disseminação das possibilidades reais de trabalho em diversas áreas profissionais. Isto 
fará com que as assistências profissionais sejam mais empáticas e eficientes promovendo a melhor estratégia de cuidado e acolhimento possível à essas dissidências.

\section{Referências}

Adelman, M. (2003). Travestis e Transexuais e os Outros: Identidade e Experiências de Vida. Revista Gênero, 4(1), 65-100. https://doi.org/10.22409/rg.v4i1.238

Associação brasileira de gays, lésbicas, bissexuais, travestis e transexuais. (2015). Identidade de Gênero. In F. Martins, L. Romão, L. Lindner, \& T. Reis (Orgs.), Manual de comunicação lgbt (pp. 16-18). ABGLT. https://unaids.org.br/wp-content/uploads/2015/09/Manual-de-Comunica\%C3\%A7\%C3\%A3oLGBT.pdf

Ávila, S. (2014). Transmasculinidades: a emergência de novas identidades políticas e sociais. Multifoco.

Ballarin, M. L. G. S. (2003). Algumas reflexões sobre grupos de atividades em terapia ocupacional. In E. M. M. Padua \& L. V. Magalhães (Orgs.), Terapia ocupacional: teoria e prática (pp. 63-76). Papirus.

Balzer, C., Lagata, C., \& Berredo, L. (2016) 2,190 murders are only the tip of the iceberg - An introduction to the Trans Murder Monitoring project TMM annual report. TGEU- Transgender Europe. TvT Publication Series. (14). https://transrespect.org/wp-content/uploads/2016/11/TvT-PS-Vol14-2016.pdf

Benneton, M. J. (1994). A terapia ocupacional como instrumento nas ações de saúde mental [Tese de Doutorado, Universidade Estadual de Campinas].

Bento, B. (2006). A reivenção do corpo: Sexualidade e Gênero na experiência transexual. GARAMOND.

Bento, B. (2012). As famílias que habitam "a família”. Sociedade e Cultura. 15(2), 275-84. Universidade Federal de Goiás. Goiânia. https://www.revistas.ufg.br/fcs/article/view/22396/13408

Bortoni, L. (2017, 20 junho). Expectativa de vida de transexuais é de 35 anos, metade da média nacional. Senado Federal, Senado Notícias- Especial Cidadania. https://www12.senado.leg.br/noticias/especiais/especial-cidadania/expectativa-de-vida-de-transexuais-e-de-35-anos-metade-da-media-nacional

Bunchaft, M. E. (2013). A jurisprudência brasileira da transexualidade: uma reflexão à luz de dworkin. Sequência, 34(67), 277-308. http://dx.doi.org/10.5007/2177-7055.2013v34n67p277

Butler, J. P. (2003). Problemas de Gênero. Feminismo e Subversão da Identidade. (Renato Aguiar, Ed. \&Trad.). Civilização Brasileira.

Cassalha, O. C., Casarin, S. T., Cortes, H. M., \& Antonacci, M. H. (2020). Vivências de pessoas transgêneras no atendimento à saúde: metassíntese qualitativa. Research, Society and Development, 9 (10). http://dx.doi.org/10.33448/rsd-v9i10.8810

Carrara, S., \& Vianna, A. (2006). "Tá lá o corpo estendido no chão...”: a violência letal contra travestis no município do Rio de Janeiro. Physis, 16(1), 233249.

Gherpelli M. H. B. V. (1996). A educação preventiva em sexualidade na adolescência. Série ideias (29), 61-72. FDE. http://www.crmariocovas.sp.gov.br/pdf/ideias_29_p061-071_c.pdf

Gonçalves, M. (2009). Psiquiatria na Prática Médica - Transtornos Psiquiátricos \&Fibromialgia. Psychiatry on line Brasil, 14 (11). http://www.polbr.med.br/ano09/prat1109.php\#cima

Hames, M. L. C, Carraro, T. E., Ramos, F. R., \& Tholl, A. D. (2008). A alteridade como critério para cuidar e educar nutrizes: reflexões filosóficas da prática. Revista Brasilera de Enfermagem, 61(2), 249-53. https://www.redalyc.org/articulo.oa?id=267019607017

Jesus, J. G. (2012). Orientações sobre identidade de gênero: conceitos e termos: Guia técnico sobre pessoas transexuais, travestis e demais transgêneros, para formadores de opinião. Fundação Biblioteca Nacional. http://www.diversidadesexual.com.br/wp-content/uploads/2013/04/G\%C3\%8ANEROCONCEITOS-E-TERMOS.pdf

Jesus, M. C. P. (2000). Educação Sexual e compreensão da sexualidade na perspectiva da enfermagem. In: R. F. R. S., M, M., \& N. R. G. (Orgs.). Um encontro de enfermagem com o adolescente brasileiro. (pp. 46-55). Aben.

Lanz, L. (2014). O Corpo da Roupa: a pessoa transgênera entre a transgressão e a conformidade com as normas de gênero. [Dissertação de Mestrado, Universidade Federal do Paraná]. Acervo Digital de Teses e Dissertações da UFPR. https://acervodigital.ufpr.br/bitstream/handle/1884/36800/R\%20\%20D\%20-\%20LETICIA\%20LANZ.pdf?sequence=1\&isAllowed=y

Louro, G. L. (2001). Teoria QUEER: Uma Política Pós-identitária para a Educação. Revista de Estudos Feminista, 9(2), 541-553. https://doi.org/10.1590/S0104-026X2001000200012

Mello, L, Perilo., M, Braz, C. A. \& Pedrosa, C. (2011). Políticas de saúde para lésbicas, gays, bissexuais, travestis e transexuais no Brasil: em busca de universalidade, integralidade e equidade. Sexualidade, salud y sociedade, (9), 7-28. https://doi.org/10.1590/S1984-64872011000400002

Melo, K. M. M. (2016). Terapia Ocupacional Social, pessoas trans e Teoria Queer: (re)pensando concepções normativas baseadas no gênero e na sexualidade. Caderno de Terapia Ocupacional da UFSCAR, 24(1), 215-223.

Minayo, S. \& Sanches, O. (1993). Quantitativo-Qualitativo: oposição ou complementaridade? Caderno de Saúde Pública, 9(3), $239-48$. 
Ministério da saúde. (2011). Portaria $\mathrm{n}^{\circ}$ 2.836, de $1^{\text {o }}$ de dezembro de 2011. Institui, no âmbito do sistema único de saúde (sus), a política nacional de saúde integral de lésbicas, gays, bissexuais, travestis e transexuais (política nacional de saúde integral lgbt). Http://bvsms.saude.gov.br/bvs/saudelegis/gm/2011/prt2836_01_12_2011.html

Ministério da saúde. (2013). Portaria n ${ }^{\circ}$ 2.803, de 19 de novembro de 2013. Redefine e amplia o processo transexualizador no sistema único de saúde (sus). Art. 13. Http://bvsms.saude.gov.br/bvs/saudelegis/gm/2013/prt2803_19_11_2013.html

Nery, J. W. \& Maranhão Filho, E. M. A. (2015). Trans-homens: a distopia nos tecno-homens. In A. G.N. Sena \& K. M. B. Souto (Orgs), Transexualidade e travestilidades na saúde. Ministério da Saúde; (pp. 25-35). http://bvsms.saude.gov.br/bvs/publicacoes/transexualidade_travestilidade_saude.pdf

Olson, J., Forbes, C., \& Belzer, M. (2011). Protocolo Olson, Forbes, Belzer - Gestão do Adolescente Transgênero. Archives of pediatrics \& adolescent medicine, 165(2), 171-176.

Pelúcio, L. (2009). Abjeção e desejo: uma etnografia travesti sobre o modelo preventivo de aids. Annablume.

Peres, W. (2005). Subjetividade das travestis brasileiras: da vulnerabilidade da estigmatização à construção da cidadania. [Tese de Doutorado, Universidade Estadual do Rio de Janeiro].

Petry, A. R., \& Meyer, D. E. (2011). Transexualidade e heteronormatividade: algumas questões para a pesquisa. Textos \& Contextos (Porto Alegre), 10(1), $193-198 . \mathrm{c}$

Pontes, J. C., \& da Silva, C. G. (2018). Cisnormatividade e passabilidade: deslocamentos e diferenças nas narrativas de pessoas trans. Revista Periódicus, 1(8), 396-417. https://doi.org/10.9771/peri.v1i8.23211

Presidência da república. (2016). Decreto $\mathrm{n}^{\circ} 8.727$, de 28 de abril de 2016. Casa civil. Dispõe sobre o uso do nome social e o reconhecimento da identidade de gênero de pessoas travestis e transexuais no âmbito da administração pública federal direta, autárquica e fundacional http://www.planalto.gov.br/ccivil_03/_ato2015-2018/2016/decreto/d8727.htm

Presidência da República. (2019). MEDIDA PROVISÓRIA No 870, DE $1^{\text {o }}$ DE JANEIRO DE 2019. Casa Civil. Estabelece a organização dos órgãos da Presidência da República e dos Ministérios. Art.44. http://www.planalto.gov.br/ccivil_03/_Ato2019-2022/2019/Mpv/mpv870.htm

Programa Conjunto das Nações Unidas sobre HIV/AIDS. (2018, 19 junho). OMS anuncia retirada dos transtornos de identidade de gênero de lista de saúde mental. https://unaids.org.br/2018/06/oms-anuncia-retirada-dos-transtornos-de-identidade-de-genero-de-lista-de-saude-mental/

Raimundo, L. H., Miranda, M. H. G., Silva, A. C., Santos, B. A. R., Silva, D., Almeida, J. C. F., Siva, L. T., \& Rocha, P. S. (2021). As Travestis, Transexuais e Transgêneros (TTTs) e a escola: Entre a (re)produção e a denúncia dos corpos abjetos. Research, Society and Development, 10(10). https://doi.org/10.33448/rsd-v10i10.18336

Rosostolato, B. (n.d.) Criança transgênero: nem menino, nem menina. UOL MBPress. https://vilamulher.uol.com.br/familia/filhos/crianca-transgenero9152.html

Silva, G. C., \& Silva, J. M. M. (2013). O ensino superior como lugar não homologado da abjeção e da diferença: sobre o devir homoerotismo. Revista do Difere, 3(6), 1-14. https://sigaa.ufpa.br/sigaa/verProducao?idProducao=182806\&key=e9b2bf1f4da31583310ea2b567e093ee

Souza, É. (2015). Projeto transexualidades e saúde pública no brasil: entre a invisibilidade e a demanda por políticas públicas para homens trans. Relatório Descritivo. Núcleo de Direitos Humanos e Cidadania LGBT (NUH-UFMG) /Departamento de Antropologia e Arqueologia (DAA-UFM). http://www.nuhufmg.com.br/homens-trans-relatorio2.pdf

Supremo Tribunal Federal. (2018). Direito à autodeterminação: STF autoriza pessoa trans a mudar prenome mesmo independentemente de cirurgia de transgenitalização. ADI 4275. http://www.stf.jus.br/portal/geral/verPdfPaginado.asp?id=400211\&tipo=TP\&descricao=ADI \% 2 F4275

Supremo Tribunal Federal. (2019). STF enquadra homofobia e transfobia como crimes de racismo ao reconhecer omissão legislativa: O Plenário concluiu nesta quinta-feira (13) o julgamento das ações que tratam da matéria e decidiu que, até que o Congresso Nacional edite lei específica, as condutas homofóbicas e transfóbicas se enquadram na tipificação da Lei do Racismo. https://portal.stf.jus.br/noticias/verNoticiaDetalhe.asp?idConteudo=414010

Viviane, V. (2014). Trans* Sexualidade: Reflexões sobre a mercantilização do sexo desde uma perspectiva transgênera. Revista Periódicus, 1(1), 174-190. https://doi.org/10.9771/peri.v1i1.10154 